\title{
Instruction strategies work out by mathematics teachers: evaluating the affect on bachelor of education
}

\author{
Sumaira Khan ${ }^{1}$, Syed Zubair Haider², Amjad Ali Bukhari ${ }^{3}$ \\ ${ }^{1}$ Doctoral Research Scholar, Department of Education, IUB, Pakistan \\ ${ }^{2}$ Assistant Professor/ Doctoral Candidate, Department of Educational Training, The Islamia University of Bahawalpur, Pakistan \\ ${ }^{3}$ Doctoral Research Scholar, BZU, Multan, Pakistan \\ For correspondence: zubairiub@hotmail.com
}

\begin{abstract}
The main objective of this research is to study the different instruction strategies implemented by Mathematics teachers and evaluating its affect on Bachelor of Education (B.Ed) level. To complete the study, two samples 34 teachers and 217 students were taken randomly. A five point Likert scale comprising 40 statements was prepared and administered to 34 teachers of teaching of mathematics, a subject taught at B.Ed level. Both statement analysis and person measurement were carried out statistically. Factors in the scale relating to instructional strategies applied by mathematics teachers in their classes were also analyzed through Inter correlation of factors. The significance of mean differences between male and female subgroups was also determined by applying Z-test. It was inferred from the statement analysis that the majority of teachers agreed that the impact of instructional strategies on teaching of mathematics and learning was positive. It was also observed that the inter-correlations among different scale factors were also significant at 0.01 and 0.05 level of significance, which showed the internal consistency among all parts of the scale.
\end{abstract}

Keywords: Instructional Strategies, Teacher, B.Ed, Mathematics, Learning

\section{Background}

The theory that teachers are made, not born has replaced with the new one that teachers are born, not made. But the concept that true teachers are born, not made is also wrong. The knowledge of desirable and undesirable qualities helps the teachers to set their goals for becoming an effective professional person. Several training institutions are producing a large number of trained teachers every year. But is this increase in teachers' quantity could improve the quality of our education system or programmes? Are they really able to shape the destiny of country? If not, then why? It means that there is deficiency in their professional development and the teachers preparing programme such as B.Ed and M.Ed are not equipping the students with the required skill in well manner resulting the deterioration in the quality of teachers (Khan, 2007).

Now a day's, different policies about teachers are framed to estimate their rational knowledge and to enhance their practical capabilities. Presently, the performance of teachers is a big question mark and radical changes are under process in the department of education. In the present era, teachers are working as a nation builder because they are more important than any of the other person because they have a responsibility on their shoulder to build a true and powerful nation. That's why; the teachers of present time are busier than ever. But the problem for the nation is the quality of teaching and its outcome, so that the objectives could be achieved. So in modern times, the evaluation of students' learning is not a single issue but the evaluation of a teachers' performance is also a big problem. 
People come to teacher education with beliefs, values, commitments, personalities and moral codes from their upbringing and schooling which affect who they are as teachers and what they are able to learn in teacher education and in teaching. Helping teacher candidates to examine critically their beliefs and values as they relate to teaching, learning, subject matter and form a vision of good teaching to guide and inspire their learning and their work is a central task of teacher education (Mukhopadhaya, 2007).

It is observed that most of the students do not like Mathematics, although students have procedural fluency but without understanding. In order to analyze deficiencies present in teaching of Mathematics the researcher tried to evaluate the teaching styles and attitude of Mathematics teachers of B.Ed classes in the Elementary colleges of Punjab. The said study is designed to observe the implication of teachers training and its practices in the classrooms. To understand the perceptions of student teachers and old teachers with and without qualification of practice in training, a survey was conducted. Its result supports the idea that training of teachers has a positive effect on the learning and teaching process.

\section{Review of Literature}

\section{Teacher Education}

Educational institutions play important role for removing darkness of ignorance from society and flourish knowledge. An educational institution also provides learning experiences to guide their student in the light of knowledge. Staff members in an institution also play significant role in this transformation of knowledge (NCTM, 2000). The teacher is the most important element in any educational system. The teacher is mainly responsible for implementation of the educational process on all stages. Therefore, it is necessary that there should be investment in the teachers' training, so that the nations' future could be secured. We can say that a teacher is a savior of a society and he filled the gap created by the ignorance. So it is clear that if we want to build a good society, we must create good teachers. In case of Pakistan, training of teachers is seemed essential for the improvement of system of education throughout the country. But the traditional styles and methods of teachers' training can be a hurdle for achieving this goal. It is very essential to create link between practice and theory and should develop the real environment of classrooms to get the better result. There should be drastic change in the training programme for teachers so that they could improve and meet the expectations of nation.

\section{Teaching of Mathematics}

The causative role of fundamental mathematics curriculum in achieving objectives cannot be over stressed especially in the schools. That's why; much emphasis has been shifted on mathematics as a core subject in the primary and secondary school levels of education (Umonyang, 1997). Mathematics subject is known as foundation because it is the base of science and technology and without science and technology no nation can achieve the task of development. Mathematics is a subject which starts from school level and provides the base for the science. So in education the importance of mathematics is undeniable and it boosts the learning process. It also brings the change in the learning process and has impact on all other subjects of science. Agwagah (1996) elaborated the role and importance of mathematics and teaching of mathematics in development of country and the society. Okolo (2006) told that the method of school teaching, having enhanced capability in mathematics, cannot meet the needs of national development. In the foundation of teaching and learning process instructional strategies plays a vital role for the countries' development. Hammond (2006) and Bruner (1996) have explained the need and indicator of changes in the proceeding of teaching mathematics. In the real world, traditional teaching of mathematics is not a mathematical problem but it helps the individual to get the idea of realistic situation and give way to the student to put the solution by their own way. 
A process of learning is hidden in it and this situation may motivate the students to learn and to understand the process that is adopted by the teachers in classrooms. It is assessed that at school level a method of teaching must be selected by the teachers which should be interesting for the students. By this way the result will be the target oriented and will increase the participation level of the learner. This will enhance the active participation in the learning process of mathematics and instructional strategies used in the process will become easy and interesting for the learner.

\section{Instructional Strategies}

Instructional strategies determine the approach that a teacher uses to achieve learning objectives (NTCM, 2000). What people learn depends not only on what they are taught but also how they are taught, their development level, and their interests and experiences. These beliefs require that much closer attention be paid to the methods chosen for presenting material (NCTM. 1991). The researches performed in the last 10 years have presented new perspective that how learners can construct their own understanding. A teachers need to engage in higher levels of mathematics to improve their content knowledge and to explore and reflect on their teaching strategies. The active participation of students in mathematics enables teachers to assess levels of competence development of all students in the classroom by walking to monitor student reactions. These strategies are specifically useful when it became a part of a daily mental mathematics lesson.

In mathematics teacher can implement instruction in different ways. Most of the mathematics skills are used in math courses and student are threaded in areas of other content. Teacher should view the content material before teaching in order to determine that what type of strategy could be helpful for student to generalize the content easily. Learning strategies such as outlining, preparing notes and through questioning techniques students may succeed. It is an easy way of self reflection helps teachers in remembering information to teach students.

Using a combination of direct instruction and strategy instruction has a great positive effect than other methods alone (Ellis, 1993; Karp \& Voltz, 2000; Swanson, 2001). Teacher should use both the teaching and instructional strategies in every lesson to make most of the approaches. Through direct instruction, a teacher should follow all the strategies for successful education and level of learning should be achieved. Although for the week and disable students these approaches are critical for maintenance of new skills. Teachers preparing programmes in Pakistan such as B.Ed program must have some shortcomings which causes the deterioration of the quality of teachers in Pakistan. Teaching strategies include the instrument of the educational procedure in the classroom situations, stages of education, theories of education, teaching activities and establish key relationships between theories and training process.

\section{Evaluative Techniques}

In teaching learning process, evaluation is very important component to facilitate students learning and to improve teachers' instruction. Through assessment techniques teachers make decisions about the students' progress. Evaluative techniques also help in planning and reshaping their instructional strategies which ultimately resulted in students' benefit. It also helps in reporting progress to students, their parents and making decision about the promotion in mathematics. Curriculum is basically designed to provide student the proper knowledge and skills for future education. It helps in moving from traditional method to new approaches. In past, evaluation of student was based on paper pencil test but now the evaluation is diverted towards the modern techniques which are equipped with latest method. Commonly, teachers depend on observation, paper pencil test and assignments to evaluate the student progress. Stake holders of the evaluation process are principal, teaching staff and class teacher which gives daily report of student evaluation. Careful planning for proper assessment is essential for a teacher to achieve the real target. For mathematics teacher, only the appropriate mathematics and teaching skills is not enough. A teacher must understand the 
different approaches of teaching as well as the techniques and teaching strategies associated with them. By understanding and evaluating each approach, a mathematics teacher can use a teaching strategy that is most effective for the given situation in the classroom (Damon, 2001). The four main approaches or areas to focus on mathematics class are the cognitive, emotional, social and physical.

\section{Research Method}

The study utilized a quantitative approach which incorporates the survey type of descriptive research.

\section{Sampling Frame}

All the teachers and students of Mathematics at 33 Government Elementary Colleges of Punjab, Pakistan were the population of the Study. Two institutions were omitted due to only one Mathematics teacher working in each Elementary College. Simple random sampling technique was utilized and 34 ( 15 female and 19 male) teachers were taken as sample of the study. This sample was used for statement analysis and person-measurement. Out of 33 colleges, 10 clusters were selected, using table of random numbers. The selected clusters represented both genders. All the students (217) associated to these clusters were included in the sample. This sample was used for the analysis of students' performance on achievement test. Out of 33 colleges there were 5 colleges exclusively for female students and 3 colleges exclusively for male students. The remaining 25 colleges related to mixed gender groups of teachers and students. Therefore the factor of gender was not taken into account while analyzing students' performance on achievement test.

\section{Instrument}

Two instruments were developed and used in the research study. A five point Likert scale, comprising 40 statements was prepared to find out the level of agreement of teachers regarding the use of instructional strategies in teaching of Mathematics at B.Ed level. A 30 items Mathematics achievement test (15 items related to Mathematics content and 15 items on methodology) to determine the performance of students in the pedagogical area of teaching of Mathematics. Both the instruments were validated and improved in the light of the opinions of the experts in the field of testing from two main universities of South Punjab.

The attitude scale was divided into 6 factors i.e. relationship between content and objectives, class environment, use of effective methods, class management, relationship between course objectives and examination system and preparation of lesson planning.

- F1: Content and Objectives (Statement 20, 21, 24, 26) $=4$

- F2: Class Environment (Statement 6, 7, 9, 14, 15, 16, 23, 28) = 8

- F3: Use of effective methods (Statement1,2,3,5,8,13,17,25,31,39) $=10$

- F4: Class management (Statement 11, 12, 19,27,29,32,34,35,37) $=9$

- F5: Course Objectives and Examination System (Statement 22, 36, 38, 40) $=4$

- F6: Preparation of Lesson planning (Statement 4, 10, 18, 30, 33) $=5$

\section{Data Collection, Analysis and Scoring}

The scale was administered to teachers to determine their agreement or disagreement with the statements related to the use of instructional strategies in teaching of mathematics at B.Ed level. Moreover, the test was administered to students and the results were recorded in tabular form. The Statements of the five point Likert scale were analyzed on the bases of percentage and mean score. The achievement test was marked by giving one mark to one correct answer. Teachers responses to the scale were analyzed by setting the norm of agreement on 3.00 mean score or the obtained score being measured on $120(40 * 3)$. The significance of difference between means of male and female 
teachers on the scale was determined by applying Z-test at 0.05 level of significance. Teachers' scores on different factors in the attitude scale were correlated using Factor Matrix method. The scores of students on two parts (content and methodology) were correlated. The Scores of 10 Selected teachers on the scale were also correlated with the mean scores on achievement test of 10 groups of students associated with respective teachers.

\section{Results}

The study was designed to analyze deficiencies present in teaching of Mathematics at B.Ed level. The researcher tried to evaluate the teaching styles and attitude of teaching of Mathematics class teachers in the Elementary colleges of Punjab. The results deal with the analysis and interpretation of the data in the light of the aims of the study.

Table 1. Scale Factor (1) Relationship between Content and Objectives

\begin{tabular}{lcccccc}
\hline \multirow{2}{*}{ Response } & \multicolumn{4}{c}{ Percentage (\%) } & Mean \\
\cline { 2 - 6 } & SA & A & UD & DA & SDA & $(\mathrm{X})$ \\
\hline $\begin{array}{l}\text { Syllabus of Mathematics fulfills the objectives. } \\
\text { The course of “teaching of Mathematics "is according }\end{array}$ & 9 & 38 & 15 & 26 & 18 & 2.82 \\
$\begin{array}{l}\text { to the mental level of students at B.Ed level. } \\
\text { I prepare notes which keep me on track. }\end{array}$ & 35 & 47 & 9 & 9 & 0 & 4.08 \\
I describe each and every aspect of the problem & 26 & 56 & 12 & 6 & 0 & 4.02 \\
\hline
\end{tabular}

The results of (table 1) showed that $41 \%$ respondents agreed that mathematics syllabus fulfill the objectives; $15 \%$ teachers were undecided while $44 \%$ teachers showed disagreement with mean score 2.82 (less than 3.00) indicating that in the opinion of majority of teachers the syllabus of Mathematics could not fulfill the educational objectives. While the second response indicates that $47 \%$ respondents agreed that the course of teaching of Mathematics is according to the mental level of students at B.Ed level; only $6 \%$ teachers were undecided while $47 \%$ teachers showed disagreement with mean score 2.76 (less than 3.00) which indicated that relatively a large number of teachers could not find the content of mathematics according to the mental level of students. In response third, $82 \%$ respondents agreed that they prepare notes which keep them on track; only $9 \%$ teachers were undecided while $9 \%$ teachers showed disagreement with mean score 4.08 (more than 3.00) which indicated that majority of the teachers prepared notes to keep them on the safe track. According to the response fourth, $82 \%$ respondents agreed that they describe each and every aspect of the problem to the students; $12 \%$ teachers were undecided while $6 \%$ teachers showed disagreement with mean score 4.02 (more than 3.00) which indicated that majority of the teachers tried to explain every aspect of the problem.

Table 2. Scale Factor (2) Class Environment

\begin{tabular}{|c|c|c|c|c|c|c|}
\hline \multirow{2}{*}{ Response } & \multicolumn{5}{|c|}{ Percentage (\%) } & \multirow{2}{*}{$\begin{array}{c}\text { Mean } \\
(X)\end{array}$} \\
\hline & SA & A & UD & DA & SDA & \\
\hline $\begin{array}{l}\text { I prompt students with questioning at each stage } \\
\text { of teaching. }\end{array}$ & 34 & 52 & 11 & 3 & 0 & 4.14 \\
\hline I motivate students for developing their interest. & 59 & 41 & 0 & 0 & 0 & 4.58 \\
\hline I develop friendly atmosphere in the classroom. & 53 & 32 & 0 & 15 & 0 & 4.38 \\
\hline $\begin{array}{l}\text { I encourage student's participation during } \\
\text { instruction. }\end{array}$ & 41 & 50 & 0 & 9 & 0 & 4.23 \\
\hline I help students when they face a problem. & 56 & 32 & 9 & 3 & 0 & 4.41 \\
\hline My students solve their problems by themselves. & 20 & 44 & 18 & 15 & 3 & 3.64 \\
\hline
\end{tabular}


I appreciate student's participation in the class room discussion.

I appreciate student's questioning about a topic.

$0 \quad 15 \quad 0$

The results of (Table 2) showed that $86 \%$ teachers prompt students with the help of questioning at different stages of problem solving, while $11 \%$ were undecided and only $3 \%$ showed disagreement with mean 4.14 which indicates that majority of the teachers guide their students. Second response indicates that $100 \%$ teachers agreed that they motivate their students and no one showed disagreement with mean 4.58 (more than 3.00) so majority of teachers try to develop the interest in students by motivating them. The result of third response showed that $85 \%$ respondents showed agreement about developing friendly atmosphere whereas $15 \%$ showed disagreement while no one is undecided about this statement and with mean 4.38 (more than 3.00) which indicates that majority of the teachers behave sociably with their students.

According to the fourth response, 91\% showed agreement towards encouraging the students' participation in studies and 9\% showed disagreement. Mean of this statement is 4.23 (more than 3.00) which indicates that most of the teachers are in the favour of encouraging their students. $88 \%$ teachers helped their students when they face problems while $9 \%$ were undecided and 3\% showed disagreement with mean 4.41 (more than 3.00) so it is concluded that mostly teachers helped their students. The result shows, in sixth response $64 \%$ teachers said that their students have an ability to solve their problems by themselves whereas $18 \%$ were undecided and $18 \%$ showed disagreement with mean 3.64 (greater than 3.00) so it is clear that most of the students have ability solve their problems. Seventh response showed that 73\% teachers showed agreement and $21 \%$ showed disagreement while 6\% were undecided with having mean 3.79 (greater than 3.00) so it indicates that most of the teachers encourage their students for taking part in discussion. 85\% teachers showed agreement and $15 \%$ showed disagreement while no one is undecided about this statement with having mean 4.05 (greater than 3.00) which indicates that mostly teachers appreciate their students on questioning.

Table 3. Scale Factor (3) Use of Effective Teaching Methods

\begin{tabular}{|c|c|c|c|c|c|c|}
\hline \multirow{2}{*}{ Response } & \multicolumn{5}{|c|}{ Percentage (\%) } & \multirow{2}{*}{$\begin{array}{c}\text { Mean } \\
(X)\end{array}$} \\
\hline & SA & A & UD & DA & SDA & \\
\hline I use method which is economical & 32 & 53 & 12 & 3 & 0 & 4.14 \\
\hline $\begin{array}{l}\text { I introduce new topics, showing relationships } \\
\text { between theory and practice }\end{array}$ & 41 & 56 & 3 & 0 & 0 & 4.38 \\
\hline $\begin{array}{l}\text { I use a process in which small groups assemble } \\
\text { to communicate with each other. }\end{array}$ & 23 & 59 & 15 & 3 & 0 & 4.02 \\
\hline I use concrete materials to motivate students & 35 & 56 & 3 & 6 & 0 & 4.2 \\
\hline $\begin{array}{l}\text { I integrate new information with what is already } \\
\text { known }\end{array}$ & 47 & 41 & 6 & 6 & 0 & 4.29 \\
\hline I use proper method for providing information & 29 & 62 & 6 & 3 & 0 & 4.17 \\
\hline In my lesson I use examples from daily life & 38 & 50 & 0 & 12 & 0 & 4.14 \\
\hline I use method which involves trial & 26 & 47 & 15 & 12 & 0 & 3.88 \\
\hline I follow a logical method to solve the problem & 15 & 59 & 12 & 14 & 0 & 3.73 \\
\hline My instruction is activity centered. & 11 & 62 & 9 & 15 & 3 & 3.64 \\
\hline
\end{tabular}

Result of (table3) revealed that in first response statement 85\% respondents showed agreement and only $3 \%$ showed disagreement while $12 \%$ were undecided with having mean 4.14 ( more than 3.00) which indicates that most of the teachers use economical methods during instruction. Second statement results shows that $97 \%$ teachers were agree and no one was disagree whereas $3 \%$ were 
undecided with having mean 4.38 (more than 3.00) which indicates that most of the teachers introduce new concepts showing relationship between theory and practice. Third statement shows that $82 \%$ teachers were agree and 3\% were disagree and only $15 \%$ were undecided with having mean 4.02 (more than 3.00) which show that most of the teachers like to make group for discussion.

Fourth response showed that $91 \%$ respondents were agree and $6 \%$ were disagree whereas $3 \%$ were undecided about the statement with having mean 4.20 (greater than 3.00) so it indicates that majority of teachers use different type of material to clarity the concept to motivate the students. Fifth response showed that $88 \%$ teachers were agree and $6 \%$ were disagree and $6 \%$ were undecided with having mean 4.29 (greater than 3.00) therefore it indicates that mostly teachers correlate previous topics with upcoming ones. Sixth response showed that $91 \%$ were agree whereas $3 \%$ were disagree and $6 \%$ were undecided with having mean 4.17 (greater than 3.00) which indicates that most of the teachers use most suitable method according to the demand of the topic.

The results of seventh statement showed that $88 \%$ were agree and $12 \%$ were disagree whereas no one was undecided about it with mean 4.14 (greater than 3.00) which showed that mostly teachers used examples from daily life for explaining the topic. Eighth response showed that $73 \%$ were agreed and $12 \%$ were disagree and $15 \%$ were undecided with mean 3.88 (greater than 3.00 ) which showed that mostly teachers used trial and error methods. Second last response showed that $74 \%$ teachers were agree $14 \%$ were disagree whereas $12 \%$ were undecided with mean 3.73 (greater than 3.00 ) which indicates that most of the teachers solve problems logically. Last response showed that $73 \%$ were agree and $18 \%$ were disagree and $9 \%$ were undecided with mean 3.64 (greater than 3.00 ) which indicates that mostly teachers' instruction are activity based.

Table 4. Scale Factor (4) Class Management

\begin{tabular}{|c|c|c|c|c|c|c|}
\hline \multirow{2}{*}{ Response } & \multicolumn{5}{|c|}{ Percentage (\%) } & \multirow{2}{*}{$\begin{array}{c}\text { Mean } \\
(X)\end{array}$} \\
\hline & SA & A & UD & DA & SDA & \\
\hline I control students in the classroom tactfully & 38 & 53 & 3 & 6 & 0 & 4.23 \\
\hline I engage students in practical activities & 20 & 65 & 12 & 3 & 0 & 4.02 \\
\hline $\begin{array}{l}\text { I adopt strategies according to the available } \\
\text { resources }\end{array}$ & 34 & 60 & 3 & 0 & 3 & 4.23 \\
\hline $\begin{array}{l}\text { Through extensive study, I gather new } \\
\text { information about the subject }\end{array}$ & 23 & 47 & 15 & 12 & 3 & 3.76 \\
\hline I help students in learning by doing. & 41 & 41 & 3 & 15 & 0 & 4.08 \\
\hline $\begin{array}{l}\text { I train and educate my students how to handle } \\
\text { the odd situation }\end{array}$ & 18 & 58 & 15 & 9 & 0 & 3.58 \\
\hline I teach students in Resource room. & 6 & 23 & 23 & 45 & 3 & 2.85 \\
\hline $\begin{array}{l}\text { To me, it is good to teach students with the help } \\
\text { of computers }\end{array}$ & 9 & 38 & 9 & 38 & 6 & 3.05 \\
\hline $\begin{array}{l}\text { To me the no. of students in the class room } \\
\text { should not be larger }\end{array}$ & 29 & 41 & 0 & 6 & 24 & 3.47 \\
\hline
\end{tabular}

Result of (table 4) expressed that in first response 91\% teachers agreed with the statement and 6\% were disagree while $3 \%$ were undecided with mean 4.23 (greater than 3.00 ) therefore it indicates that most of the teachers tactfully control their students in classrooms. In response second $85 \%$ respondents agreed with the statement and only 3\% were disagree and $12 \%$ were undecided about the statement with mean 4.02 (greater than 3.00) indicated that mostly teachers engage their students in practical activities. In third response $94 \%$ teachers were agreed and 3\% were disagree and only 3\% were undecided with mean 4.23 (greater than 3.00) which indicates that teachers adopt strategies according to the available resources. 
In fourth response, the result showed that $70 \%$ teachers agreed with the statement and $15 \%$ were disagree and $15 \%$ were undecided with mean 3.76 (greater than 3.00 ) which indicates that many teachers do extensive study to get more innovative and latest information regarding topics they taught. Result of response fifth identified that $82 \%$ teachers were agree and $15 \%$ were disagree and $3 \%$ were undecided with mean 4.08 (greater than3.00) which indicates that most of the teachers helped their students in self studies. The result of response sixth showed that $76 \%$ teachers agreed with the statement and 9\% were disagree and 15\% were undecided with mean 3.58 (greater than 3.00) so it indicates that many teachers train their students to handle the difficult situation.

In response seventh results showed that only $29 \%$ teachers were agree whereas $48 \%$ were disagree and $23 \%$ were undecided about the statement with mean 2.85 (less than 3.00 ) which indicates that most of the teachers do not use resource room for teaching. In eighth response the results showed that $47 \%$ teachers were agree and $44 \%$ were disagree whereas $9 \%$ were undecided with mean 3.05 (greater than 3.00) which shows that most of the teachers like to take help with computers. Last response showed that $70 \%$ teachers were agree and $30 \%$ were disagree whereas no one is undecided with mean 3.47 (greater than 3.00) which indicates that most of teachers prefer small classes (less students in class).

Table 5. Scale Factor (5) Relationship between Course Objectives and Examination

\begin{tabular}{|c|c|c|c|c|c|c|}
\hline \multirow{2}{*}{ Response } & \multicolumn{5}{|c|}{ Percentage (\%) } & \multirow{2}{*}{$\begin{array}{l}\text { Mean } \\
(X)\end{array}$} \\
\hline & SA & $\mathrm{A}$ & UD & $\mathrm{DA}$ & SDA & \\
\hline $\begin{array}{l}\text { The topics given in the course out-line are } \\
\text { correct }\end{array}$ & 9 & 38 & 12 & 15 & 26 & 2.88 \\
\hline $\begin{array}{l}\text { The syllabus is deeply concerned with the daily } \\
\text { life of Students }\end{array}$ & 6 & 29 & 12 & 21 & 32 & 2.55 \\
\hline $\begin{array}{l}\text { I am satisfied with the present examination } \\
\text { system }\end{array}$ & 3 & 26 & 9 & 21 & 41 & 2.29 \\
\hline $\begin{array}{l}\text { There should be refresher courses for } \\
\text { mathematics teachers regularly }\end{array}$ & 47 & 47 & 0 & 0 & 6 & 4.29 \\
\hline
\end{tabular}

Result of (table 5) indicated that in first response $47 \%$ were agree and $41 \%$ were disagree whereas $12 \%$ were undecided with mean 2.88 (less than 3.00) which indicates that teachers are satisfied with the course outline. Second statement showed that 35\% teachers were agree and 53\% were disagree whereas $12 \%$ were undecided with mean 2.55 (less than 3.00) which indicates that most of the teachers were not agree with the syllabus content because they are not related to daily life problems. Third statement showed that only $29 \%$ teachers were agree with the statement and $62 \%$ were disagree whereas $9 \%$ were undecided with mean 2.29 (less than 3.00) which indicates that most of the teachers are not satisfied with the present examination system. Last statement showed that $94 \%$ teachers were agree and only $6 \%$ were disagree whereas no one is undecided with mean 4.29 (greater than 3.00) which showed that most of the teachers were agreed with the regular conduct of refresher courses for mathematics teachers.

Table 6. Scale Factor (6) Preparation of Lesson Planning

\begin{tabular}{|c|c|c|c|c|c|c|}
\hline \multirow{2}{*}{ Response } & \multicolumn{5}{|c|}{ Percentage (\%) } & \multirow{2}{*}{$\begin{array}{c}\text { Mean } \\
(X)\end{array}$} \\
\hline & SA & $\mathrm{A}$ & UD & DA & SDA & \\
\hline $\begin{array}{l}\text { While developing the lesson I use examples } \\
\text { related to the topic }\end{array}$ & 56 & 26 & 12 & 6 & 0 & 4.32 \\
\hline I plan lesson according to the logical order & 32 & 53 & 6 & 9 & 0 & 4.08 \\
\hline
\end{tabular}


I focus on individual differences while planning a lesson.

I present information in small units.

$\begin{array}{cccccc}26 & 47 & 12 & 12 & 3 & 3.82 \\ 20 & 53 & 9 & 18 & 0 & 3.76 \\ 26 & 56 & 12 & 6 & 0 & 4.02\end{array}$

I give a number of solutions to arrive at a

conclusion

Results of (table 6) showed that $82 \%$ teachers were agree and $6 \%$ were disagree and $12 \%$ were undecided with mean 4.32 (greater than 3.00) which indicates that most of the teachers used different examples during lesson planning. Second statement showed that $85 \%$ teachers were agree and $9 \%$ were disagree whereas $6 \%$ were undecided with mean 4.08 (greater than 3.00 ) which shows that most of the teachers logically plan their lesson. Third statement showed that $73 \%$ teachers were agree and $15 \%$ were disagree whereas $9 \%$ were undecided with mean 3.82 (greater than 3.00 ) which indicates that mostly teachers focus on individual differences during lesson planning. Second last statement showed that $73 \%$ teachers were agree and $18 \%$ were disagree whereas $9 \%$ were undecided with mean 3.76 (greater than 3.00) which indicates that most of the teachers explain their lessons in small units. Last statement showed that $82 \%$ teachers were agree and $6 \%$ were disagree and $12 \%$ were undecided with mean 4.02 (greater than 3.00) which indicates that mostly teachers present different solutions of the problem.

Table 7. Gender wise Score on Scale Score

\begin{tabular}{|c|c|c|c|c|}
\hline & $\mathrm{N}$ & Score & Mean & SD \\
\hline Male & 19 & $\begin{array}{l}138,112,128,118,171,121,158,146,190,173, \\
166,143,110,170,153,160,112,170,168\end{array}$ & 147.74 & 24.03 \\
\hline Female & 15 & $\begin{array}{l}\text { 126, 152, 131, 188, 117, 146, 177, 111, 156, 166, } \\
194,147,114,168,108\end{array}$ & 146.73 & 27.33 \\
\hline
\end{tabular}

To determine the difference between mean scores of male and female teachers on the scale is statistically significant or not, Z-test was applied. Table value of $Z$ at 0.05 level of significance $=1.96$ while calculated value was 0.11 , which was smaller than the table value $(0.11<1.96)$. The results showed that difference is insignificant. Mathematics teachers of both genders have positive attitude towards using supportive instructional strategies in their teaching.

Table 8. Inter-correlation coefficients between Scale-factors

\begin{tabular}{lllllll}
\hline & F1 & F2 & F3 & F4 & F5 & F6 \\
\hline Content and Objectives & 1.000 & & & & & \\
Classroom Environment & $0.776^{*}$ & 1.000 & & & & \\
Effective Methods & $0.608^{* *}$ & $0.781^{*}$ & 1.000 & & & \\
Class Management & $0.608^{*}$ & $0.761^{*}$ & $0.788^{* *}$ & 1.000 & & \\
Course Objectives and Exam & $0.546^{*}$ & $0.675^{* *}$ & $0.647^{*}$ & $0.731^{*}$ & 1.000 & \\
Lesson Planning & $0.729^{*}$ & $0.874^{* *}$ & $0.77^{*}$ & $0.820^{*}$ & $0.666^{*}$ & 1.000 \\
\hline
\end{tabular}

${ }^{* *}$ Correlation is significant at the 0.01 level. ${ }^{*}$ Correlation is significant at the 0.05 level.

Coefficients of Correlation between all factors has high positive value which showed that all factors in the Scale were associated and correlated with one another, Which also determined the internal consistency and validity of the scale. 
Table 9. Students' Achievement and Teachers' Score on Scale

\begin{tabular}{cccc}
\hline $\begin{array}{c}\text { Teachers' } \\
\text { Sr. No }\end{array}$ & $\begin{array}{c}\text { Teachers' Score on } \\
\text { Scale }\end{array}$ & $\begin{array}{c}\text { No. of Students } \\
\text { attached }\end{array}$ & $\begin{array}{c}\text { Students' Mean score } \\
\text { on Achievement test }\end{array}$ \\
\hline 1 & 138 & 13 & 24 \\
2 & 160 & 12 & 20 \\
3 & 173 & 32 & 25 \\
4 & 146 & 32 & 24 \\
5 & 128 & 32 & 21 \\
6 & 117 & 32 & 19 \\
7 & 121 & 32 & 22 \\
8 & 126 & 17 & 24 \\
9 & 118 & 13 & 22 \\
10 & 131 & 11 & 20 \\
\hline
\end{tabular}

The correlation coefficient between students' achievement and their teachers' attitude was computed by using Spearman's rank correlation coefficient formula.

$r=1-\frac{6 \sum d^{2}}{n\left(n^{2}-1\right)}$

The value was calculated to be 0.45 . This positive, though moderate, value of correlation coefficient showed that the performance of attached students was positively correlated and to the scores of their respective mathematics teachers. It was inferred that if teachers applied supported instructional strategies in mathematics classes their students' performance would be better.

\section{Discussion and Conclusion}

It is evident from results that majority of teachers were practicing economical methods of teaching mathematics in classes and a large majority of respondents was applying methods for connecting theory and practice together. Most of respondents used to arrange small group teaching classes. A large majority of teachers was using examples in explaining mathematical concepts while many respondents were motivating students with the help of concrete materials. Majority of teachers was applying question answer techniques in explaining mathematical concepts. All respondents were in the favour to motivate students by effective methods. A large majority of teachers was using past experiences and new information together in explaining mathematical concepts. A sizeable number of respondents were developing friendly atmosphere in the classes. Many teachers were using logical order during planning of Mathematics lesson.

A greater part of respondents was using techniques to control students in classrooms and teachers were engaging students in useful activities. A large majority of teachers was using proper method in explaining mathematical concepts. Many of teachers were encouraging students' participation during instruction. Mostly teachers were helping their students in problematic situation. Teachers were also providing help to their students in difficult situation. A large majority of teachers was using examples from daily life in developing their lessons. Many respondents were focusing on individual differences in explaining mathematical concepts. Majority of teachers were applying strategies according to the available resources.

A large majority of teachers believed that syllabus of mathematics not fulfilled the objectives. Half of the teachers were in favour and half were against that course of teaching of mathematics is according to the mental level of students while many of them believed that given topics in the course outline are 
correct. Most of teachers were appreciating students' participation in the classroom. Many of them were preparing notes for good teaching. A large majority of teachers was applying trial and error method for students while most of teachers were explaining each aspect of the problem. Majority of respondents was in the habit of studying their subject and respondents were appreciating students' involvement during instruction. Most of teachers were encouraging students in learning by doing. A large majority of teachers was presenting their lessons in small units while most of teachers were following the logical method to solve the problem.

A large majority of respondents was building the confidence of students so they can handle the different difficult situations and teachers were in favour of giving many solutions for a given problem. Most of respondents were not using resource room for teaching and teachers were in favour of using computers in teaching of mathematics. A large portion of teachers believed that syllabus was not related to daily life and they also believed that they feel comfortable with small strength of students in classrooms. Many of respondents were not satisfied with the examination system while majority of respondents was using activity based instruction. A large majority of teachers was in favour of regular refresher courses for mathematics teachers. On a large number of statements, teachers mean score were high in magnitude. A large majority of teachers showed their positive attitude towards using supportive instructional strategies. The difference between the mean scores of male and female teachers on scale was statistically insignificant. The factors covered in the scale were inter-correlated with one another, showing internal consistency of factors and proving the validity of the instrument. Scores of students on two test components were positively correlated. Students' achievement was related to their teachers' attitude towards using supportive instructional strategies in mathematics classes.

\section{Recommendations}

Future researchers may evaluate the impact of instructional strategies applied on some other courses being taught at B.Ed level. Sample for the future studies may be extended to provinces other than Punjab. Elements like objectives, course content and modes of assessment at B.Ed level may also be studied. As researchers of this study demanded that course content of 'Teaching of Mathematics at B.Ed level may be redesigned to make it according to the mental level of B.Ed trainees; to integrate it with the instructional objectives; to get suitable help/text books prepared and to relate it to the daily life of trainees. Teaching of Mathematics classes may be arranged in special resource rooms so that students' learning could be concrete and permanent. The examination system at B.Ed level in general and for the pedagogical course in teaching of Mathematics may be improved especially in the areas of preparation selection type items, administering and scoring.

\section{References}

Agwagah, U. N. V. (1996). Instructional deficiency in some secondary school mathematics topics; challenge of Mathematics educators for future Mathematics education. A paper presented at the 33rd annual conference of mathematical association of Nigeria. (MAN).

Burner, J. (1996). Toward a theory of instruction. New York: Norton.

Damon, A. (2001). Evaluation of the Different Approaches E Techniques to Make Teaching Mathematics Skills Effective: McGraw-Hill

Ellis, E. S. (1993). Integrative strategy instruction: A potential model for teaching content area subjects to adolescents with learning disabilities. Journal of Learning Disabilities, 26(6), 358-383.

Hammond, L.D. (2006). Powerful Teacher Education. P: 97 USA: HB Printing.

Khan M. A. (2007). Teacher's Handbook of Methods and Techniques. Delhi.

Karp, K. S., \& Voltz, D. L. (2000). Weaving mathematical instructional strategies into inclusive settings. Intervention in School and Clinic, 35(4), 206-215.

Mukhopadhaya, M. (2007). Quality Management of Schools. New Delhi: NIEPA

National Council of Teachers of Mathematics (2000). Principle and standards for school mathematics (NCTM): Reston.

National Council of Teachers of Mathematics (1991). Professional Standards for Teaching Mathematics: Reston.

Okolo, U. P. (2006). The challenges of Universal Basic Education (UBE). The role of secondary mathematics. Paper presented at the 43rd Annual Conference of Mathematical Association of Nigeria (MAN) Bauchi; Nigeria. P1-13 
Swanson, H. L. (2001). Searching for the Best Model for Instructing Students with Learning Disabilities. Focus on Exceptional Children, 34(2), 1-15.

Umonyang, I. E. (1997). Maximizing student's achievement in mathematics thought multi grade classroom teaching approach; paper presented at the 40th national conference of Science Teacher Association of Nigeria (STAN) p.25 